Revista Brasileira de Farmacognosia Brazilian Journal of Pharmacognosy 21(4): 744-753, Jul./Aug. 2011

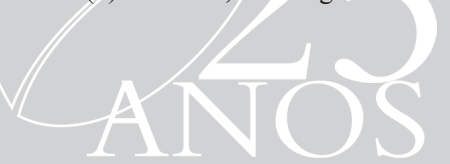

Review

Received 25 Aug 2010

Accepted 16 Nov 2010

Available online 20 May 2011

Keywords:

cancer

ethnopharmacology

medicinal plants

ISSN 0102-695X

doi: 10.1590/S0102-695X2011005000087

\section{Phytochemical and pharmacological notes of plants indicated to treat tumors in Brazil}

\author{
Joabe Gomes de Melo, ${ }^{1,2}$ Ariane Gaspar Santos, ${ }^{2}$ Elba Lúcia \\ Cavalcanti de Amorim, ${ }^{2}$ Silene Carneiro do Nascimento, ${ }^{3}$ Ulysses \\ Paulino de Albuquerque ${ }^{*, 1}$
}

\author{
${ }^{I}$ Departamento de Biologia, Universidade Federal Rural de Pernambuco, \\ Brazil, \\ ${ }^{2}$ Departamento de Ciências Farmacêuticas, Centro de Ciências da Saúde; \\ Universidade Federal de Pernambuco, Brazil, \\ ${ }^{3}$ Departamento de Antibióticos, Universidade Federal de Pernambuco, \\ Brazil.
}

\begin{abstract}
The plants used in traditional medicine have been considered an important source of molecules with pharmacological activity, including antitumor. The aim of this study was to present a pharmacological description and the phytochemical components related to antitumor activity of thirty plants commonly cited in Brazil to treat tumors as well as offering an overview of approaches that are necessary for the development of herbal medicines from these resources. In the search for studies with these plants, five database were used (SciELO, Scirus, Scopus, Biological Abstracts and Web of Science), with the following keywords: tumor AND Species AND cancer. We consider all the scientific synonyms of species available in the Tropicos ${ }^{\circledR}$ database (http://www.tropicos. org/). We surveyed papers from the period between 1980 and 2008. Twnety one species $(70 \%)$ have at least one evaluation of a class of molecule or metabolite isolated against a pharmacological model. Most species $(60 \%)$ has in vivo studies. Of the thirty plant species, two stood out for having pharmacological studies in vitro, in vivo and clinical with positive results: Chelidonium majus L., Papaveraceae, and Aloe arborescens Mill., Xanthorrhoeaceae. Although there is generally a good activity of species presented here, there is a need for further studies in order to evaluate the possibility of developing some byproduct.
\end{abstract}

\section{Introduction}

Brazil has a unique biological and cultural diversity that is reflected in a popular pharmacopeia very diversified, consisting mainly of medicinal plants (Melo et al., 2007). The record of popular uses of these plants has been performed by the ethnobotany, which has contributed both to nature conservation and for developing new industrial products (Oliveira et al., 2009).

Plants used in folk medicine have been considered an important source of molecules with pharmacological activity, including antitumor. Many studies have demonstrated that plants used in traditional medicine for treating cancer and tumors showed good pharmacological activity in vitro and/or in vivo using different experimental models (Ashida et al., 2010; Yang et al., 2007; Itharat et al., 2004).

This paper aims to lift the state of art of plants that are cited in ethnobotanical surveys to treat tumors in order to explain the existing gaps, as well as offering an overview of approaches that are necessary for the development of herbal medicines from these resources.

\section{Materials and Methods}

This work was based on a survey of ethnobotanical and ethnopharmacological studies developed in Brazil with medicinal plants. We used five database to rescue these works: SCIELO, SCIRUS, SCOPUS, Biological Abstracts and Web of Science. We used the following keywords: ethnobotany AND Brazil AND medicinal plants; ethnobotany AND Brazilian medicinal plants; Ethnopharmacology AND Brazil AND medicinal plants; and Ethnopharmacology AND Brazilian medicinal plants. We rescued works from the period between 1980 and 2008. From selected works, it was performed a detailed search for all plants that were cited in these studies and popularly referred as anti- 
tumor. Subsequently, we conducted a further search of articles for each species, with the intention of rescuing the phytochemical and pharmacological works on them. All scientific names were checked and updated based on the Missouri Botanical Garden database (http//www. tropicos.org).

\section{Results}

We recorded 84 plants reported in the ethnobotany/ethnopharmacological literature that met our inclusion criteria. Below we summarize the studies on the anti-tumor activity of each plant species that we have found in our search. We succinctly describe pharmacological aspects of the thirty plant species which were reported in at least one study and molecules that have been isolated from them. For the other 54 plants we have not found works related to antitumor activity (see Melo et al., 2011).

\section{Anacardium occidentale L., Anacardiaceae}

Anacardic acid, a phytochemical component of this and other plant species, such as Ginkgo biloba and Ozoroa insignis (Sung et al., 2008; Rea et al., 2003), is a molecule of phenolic nature and is one of the major components of the fruit of this plant (Paramashivappa et al., 2001). Anacardic acid has cytotoxic effects against several cancer cell lines in vitro (Rea et al., 2003). In addition, anacardic acid sensitizes tumor cells to the cytotoxic effects of ionizing radiation (Sun et al., 2006). This molecule has proven to be a potent inhibitor of NF$\kappa \mathrm{B}$ activation, which likely explains its anti-proliferative, anti-angiogenic, pro-apoptotic and anti-metastatic effects (Sung et al., 2008). The polysaccharides, oligosaccharides, $\beta$-galactose and proteins present in the cashew resin of this plant have shown inhibitory activity against sarcoma-180 cells implanted in mice (Monthé et al., 2008). In a clinical study, Vicente and colleagues (Vicente, 2009) evaluated the use of a combination of $A$. occidentale and Gliricidia sepium extracts for the treatment of basal carcinoma in 37 patients. Upon topical treatment of the extracts over the lesion in the facial region, with an average of eight applications, it was found that 35 lesions were no longer detected during a routine exam between two to 84 months following the treatments.

\section{Forsteronia refracta Müll. Arg., Apocynaceae}

The substance extracted from this plant termed SL0101 is a kaempferol glycoside that inhibits proliferation of the human breast cancer cell line MCF-7 by inducing cell cycle arrest at the G1 phase through the action of the ribosomal S6 kinase (RSK) (Smith et al., 2005). This same molecule did not alter the proliferation of a control breast cell line (MCF$10 \mathrm{~A}$ ), although it did inhibit RSK in these cells (Smith et al., 2005). Other molecules belonging to the same class as SL0101 have been isolated from $F$. refracta and have also been shown to inhibit RSK (Xu et al., 2006).

\section{Hancornia speciosa Gomes, Apocynaceae}

The ethanol extract of the leaves of this plant exhibit anti-proliferative activity in different cancer cell lines in vitro (Endringer et al., 2009).

Himatanthus obovatus (Müll. Arg.) Woodson, Apocynaceae

The ethanol extracts of the leaves and roots of this plant exhibit cytotoxic activity against cerebrovascular, colon carcinoma, melanoma and leukemia cells in vitro (Mesquita et al., 2009).

\section{Orbignya phalerata Mart., Arecaceae}

The ethanol extract of the mesocarp/epicarp of this plant exerts cytotoxic effects preferentially in tumor cell lines when compared to non-tumor cells (Rennó et al, 2008).

\section{Acanthospermum hispidum DC., Asteraceae}

The methanol extract of the leaves of this plant exerts cytotoxic effects against lung (A-427), bladder (5637) and breast cancer (MCF-7) cells (Mothana et al., 2009). The ethyl acetate extract of the plant and its fractions exhibit anti-tumor activity in mice (Rajendran \& Deepa, 2007).

\section{Calendula officinalis L., Asteraceae}

The laser-activated aqueous extract of $C$. officinalis flowers exhibit anti-proliferative activity in different cancer cell lines in vitro. The mechanism of inhibition of this extract was shown to involve cell cycle arrest at the G0/G1 phase and induction of caspasemediated apoptosis (Jiménez-Medina et al., 2006). In addition, the extract also inhibits the growth of tumors in vivo (Jiménez-Medina et al., 2006). Two triterpene glycosides isolated from the flowers of this plant, calenduloside F 6'-O-n-butyl-ester and calenduloside G 6'-O-methyl ester, showed cytotoxic activity against colon cancer, leukemia and melanoma cell lines when used at concentrations below $20 \mu \mathrm{M}$ (Ukiya et al., 2006).

\section{Silybum marianum (L.) Gaertn., Asteraceae}


Silibinin, a flavonoid present in the fruit of $S$. marianum, inhibits the growth and reduces the viability of three mouse prostate carcinoma cell lines (Tyagi et al., 2002). Treatment of the cell lines H-7 and I- 8 with $100 \mu \mathrm{M}$ of silibinin results in cell cycle arrest at the G1 phase when treated for 12 and $24 \mathrm{~h}$ and in arrest at the S phase when treated for $48 \mathrm{~h}$ (Tyagi et al., 2002). In addition, silibinin strongly inhibits DNA synthesis and induces apoptosis in these cell lines (Tyagi et al., 2002). Moreover, this molecule also has antiproliferative activity in breast and ovarian cancer cell lines (Scambia et al., 1996). Silimarin, isolated from the fruit this plant, also exerts chemopreventive effects in skin and prostate cancer cells in several experimental models in vivo and in vitro (Deep \& Agarwal, 2007). Bhatia et al. (1999) demonstrated that, when used in combination, silibinin and silimarin inhibit growth and DNA synthesis in breast, cervical and prostate cancer cells. These authors also suggest that the anti-tumor and chemopreventive activities of this combination treatment may be attributed to silibinin. Other studies suggest that both silibinin and silimarin are effective in vivo and in vitro for the prevention and treatment of cancer (Kim et al., 2009; Ramasamy \& Agarwal, 2008; Agarwal et al., 2007; Hoh et al., 2007; Zhong et al., 2006; Chen et al., 2005; Davis-Searles et al., 2005; Singh \& Agarwal, 2005).

Tabebuia impetiginosa (Mart. ex DC.) Standl, Bignoniaceae

$\beta$-lapachone, a quinone derived from the bark of this plant species, has shown significant cytotoxic activity against multiple myeloma (IC50 4-16 $\mu \mathrm{M}$ ) and drug-resistant cell lines. In addition, this molecule can induce apoptosis in multiple myeloma cells (Gupta et al., 2002) and can inhibit growth and induce apoptosis in human colon and prostrate carcinoma cells (Lee et al., 2005). $\beta$-lapachone exhibits anti-metastatic and antiinvasive activities against human hepatocarcinoma cells (Kim et al., 2007). The $\beta$-lapachone in combination with ionizing radiation in vitro and in vivo produced more significant cytotoxic and anti-tumor (mice) effects than when administered alone (Park et al., 2006). Additional studies have contributed to our understanding of the mechanisms of action of $\beta$-lapachone (Lee et al., 2006; Woo et al., 2006; Choi et al., 2003a; Choi et al., 2003b).

\section{Symphytum officinale L., Boraginaceae}

The ethanol extract of the roots of this plant exhibit a $57.6 \%$ cytostatic (inhibition of mitosis) effect on human cervical epithelial carcinoma cells (Roman et al., 2008).

\section{Carica papaya L., Caricaceae}

5,7-Dimethoxycoumarin is produced by some plant species, including C. papaya (Alesiani et al., 2008). In the human melanoma cell line A375, this molecule exhibited cytostatic activity and blocked the cell cycle at the G0/G1 phase (Alesiani et al., 2008). Lycopene, a carotenoid also present in the papaya plant, has been shown to have anti-metastatic and antiinvasive activities in cancer cell lines and can inhibit the cell cycle and induce apoptosis (Breemen \& Pajkovic, $2008)$. The $n$-hexane extract of papaya seeds induces apoptosis of the leukemia cell line HL-60 (Nakamura et al., 2007). Benzyl isothiocyanate, which is isolated from the fruit of this plant, exhibits cytotoxic activity against colon cancer cells (Miyoshi et al., 2006).

\section{Maytenus ilicifolia (Schrad.) Planch., Celastraceae}

Pristimerin, a triterpene isolated from the bark and root of this plant, exhibits anti-proliferative activity in HL-60 cells by inhibiting DNA synthesis and apoptosis (Costa et al., 2008). This molecule also induces apoptosis of prostate cancer cells (Yang et al., 2008). Shirota et al. (1994) isolated the aromatic triterpene 6-oxotingenol, which was shown to have cytotoxic activity against three different tumor cell lines (L-1210, P-388 and KB) when used at concentrations between 2.6 and $30 \mu \mathrm{g} / \mathrm{mL}$. Erythrodiol, a terpenic compound isolated from the leaves of this plant, exhibits cytotoxic activity against $\mathrm{KB} / \mathrm{S}$ cells when used at a concentration of $7 \mu \mathrm{g} / \mathrm{mL}$ (Ohsaki et al., 2004).

\section{Chenopodium ambrosioides L., Amaranthaceae}

The hydroalcoholic extract of wormseed leaves exhibits anti-tumor activity in mice (Nascimento et al., 2006). Ascaridol exhibits in vitro antineoplastic activity in different tumor cell lines (Efferth et al., 2002).

\section{Manihot esculenta Crantz, Euphorbiaceae}

The aqueous extract of the leaves of this plant has cytotoxic activity against cervical and ovarian adenocarcinoma cells (IC50 57 and $38 \mu \mathrm{g}$ / $\mathrm{mL}$, respectively) (Yusuf et al., 2006). Linamarin, a cyanogenic glycoside isolated from this plant, combined with the linamarase enzyme is more cytotoxic against breast cancer, colon adenocarcinoma and leukemia cells than when pure or crude linamarin extract is used alone (Idibie et al., 2007). Two triterpenic acids, esculentoic acids $\mathrm{A}$ and $\mathrm{B}$, exhibit cytotoxic activity against ovarian cancer cells and have IC50 values of 6.4 and $4.8 \mathrm{mg}$ / $\mathrm{mL}$, respectively (Chaturvedula et al., 2003). 


\section{Anadenanthera colubrina (Vell.) Brenan, Fabaceae}

An acidic heteropolysaccharide isolated from the resin of this plant exhibits anti-tumor activity against solid and ascitic tumors in rats when administered at a dose of $100 \mathrm{mg} / \mathrm{kg}$ (Moretão et al., 2004).

\section{Bauhinia forficata Link, Fabaceae}

The HY52 substance, which as isolated from the leaves of this plant, inhibits the growth of cervical adenocarcinoma cells (IC50 $0.11 \mu \mathrm{M}$ ) and induces apoptosis by promoting cell cycle arrest at the G1 phase (Lim et al., 2006).

\section{Copaifera langsdorffii Desf., Fabaceae}

Kaurenoic acid, a diterpene isolated from the oil/resin of this plant, inhibits the growth of leukemia $(95.3 \%)$, breast carcinoma and colon cancer cells $(47.5 \%)$ when used at a concentration of $78 \mu \mathrm{M}$ (CostaLotufo et al., 2002).

\section{Copaifera multijuga Hayne, Fabaceae}

The hexane and chloroform fractions of the oil extracted from this plant exhibit anti-neoplastic activity in mice (Gomes et al., 2008). In addition, the resin oil and its fractions exhibit anti-tumor activity against a melanoma cell line in vivo and in vitro (Lima et al., 2003).

\section{Senna occidentalis (L.) Link, Fabaceae}

The ethanol extract of the leaves of this plant has selective cytotoxic activity against a central nervous system cancer cell line and has an IC50 of $3.9 \mu \mathrm{g} / \mathrm{mL}$ (Calderón et al., 2006).

Aloe arborescens Mill., Xanthorrhoeaceae

Clinical studies have demonstrated that cancer patients treated with a chemotherapeutic drug in combination with an extract of $A$. arborescens respond better than when treated with the chemotherapeutic alone (Lissoni et al., 2009). A. arborescens exerts a chemopreventive effect in hamsters with experimentally-induced pancreatic cancer (Furukawa et al., 2002). Aloin exhibits cytotoxic activity against a human colorectal cancer cell line and has an IC50 of 293.1 $\pm 32.7 \mu \mathrm{M}$ (Jin et al., 2005).

Aloe vera (L.) Burm. f., Xanthorrhoeaceae

Aloe-emodin (1,8-dihydroxy-3-[hydroxymeth yl]-anthraquione; inhibits cellular viability and induces apoptosis and cell cycle arrest at the G2 phase in human bladder cancer cells (Lin et al., 2006). In addition, this substance exhibits cytotoxic activity against neuroectodermal tumor cells in vitro and inhibits the growth of neuroblastomas in vivo (Pecere et al., 2000). It also inhibits proliferation and induces apoptosis of glioma cells (Acevedo-Duncan et al., 2004) and human gastric carcinoma cells (Chen et al., 2007). At a concentration of $10 \mu \mathrm{M}$, aloe-emodin exhibits antiproliferative activity against the Merkel carcinoma cell line, which is an aggressive and rare type of sun-induced skin tumor that primarily affects elderly individuals (Wasserman et al., 2002). Aloctin I, a type of lectin isolated from the leaves of the A. vera plant, prevents tumor growth in mice when administered prior to tumor implantation (Akev et al., 2007).

\section{Rapanea guianensis Aubl., Primulaceae}

Rapanone (2,5-dihydroxy-3-tridecyl-1,4benzoquinone, which is isolated from the bark of this plant, exhibits cytotoxic activity against breast, colorectal, larynx and gastric cancer cells when used at doses between 21 and $29.4 \mu \mathrm{M}$ (Cordero et al., 2004).

Boerhavia diffusa L., Nyctaginaceae

The hydroalcoholic extract and an alkaloid (termed punarnavine) derived from this plant inhibit the metastatic progression of melanoma in mice (Manu \& Kuttan, 2009; Leyon et al., 2005). In addition, the hydroalcoholic extract prevents skin carcinogenesis induced by 7,12-dimethylbenz(a)anthracene(DMBA) in mice (Bharali et al., 2003). Moreover, several rotenoids isolated from this plant, including the boeravinones $G$ and $\mathrm{H}$, inhibit the activity of a breast cancer resistance protein (BCRP/ABCG2) (Ahmed-Belkacem et al., 2007).

\section{Chelidonium majus L., Papaveraceae}

Chelidonine, sanguinarine and chelerythrine, which are alkaloids isolated from this grass, induce cell death by apoptosis and/or necrosis in uveal melanoma cells (Kemény-Beke et al., 2006). Chelidonine induces cell death of pancreatic cancer cells via cell cycle arrest at prophase and metaphase (Gansauge et al., 2001). The ethanol extract of this plant exhibits antitumorigenic activity in mice with experimentallyinduced hepatocarcinoma (Biswas et al., 2008). Ukrain, a semi-synthetic compound composed of triphosphoric acid and purified alkaloids derived from C. majus, which is a registered drug in Mexico and in some countries of the former Soviet Union, exhibits 
cytotoxic activity against several tumor cell lines and has IC50 concentrations varying between 6.2 and 31.2 $\mu \mathrm{M}$ (Lanvers-Kaminsky et al., 2006). It also induces apoptosis of Jurkat T lymphoma cells (Habermehl et al., 2006). Clinical studies demonstrated that both treatment of advanced pancreatic cancer patients with ukrain alone or in combination with gemcitabine nearly doubled the average survival time of the patients (Gansauge et al., 2002). The nucleases isolated and purified from the sap of C. majus, referred to as CMN1 and CMN2, induce the apoptosis of HeLa cells when used at a concentration of $13.3 \mathrm{ng} / \mathrm{mL}$ (Nawrot et al., 2008).

\section{Plantago major L., Plantaginaceae}

The methanol extract of the leaves of this plant inhibit the growth of human breast adenocarcinoma and melanoma cells by $50 \%$ when used at a concentration of $46.5 \mu \mathrm{g} / \mathrm{mL}$ (Gálvez et al., 2003). In addition, treatment of ovarian and cervical carcinoma cells with $1 \mu \mathrm{g} / \mathrm{mL}$ of the methanol extract of the aerial parts of the plant reduce the cell numbers by $82 \%$ and $59 \%$, respectively (VelascoLezama et al., 2006). Moreover, the aqueous extract of the plant exhibits anti-tumor activity in the Ehrlich's ascites tumor experimental mouse model (Ozaslan et al., 2007).

Plumbago scandens L., Plumbaginaceae

Several substances that exhibit cytotoxic activity have been isolated from $P$. scandens; however, plumbagin, which is isolated from the aerial parts of the plant, is the most studied. Plumbagin has cytotoxic activity against breast cancer and melanoma cells, with an IC50 of 1.28 and $1.39 \mu \mathrm{M}$, respectively (Nguyen et al., 2004). In addition, it inhibits the growth of epithelial cancer (Wish, IC50 21.2 $\mu \mathrm{M}$ ), lung carcinoma (Calu-1, IC50 $25 \mu \mathrm{M}$ ) and cervical carcinoma (HeLa, IC50 21.5 $\mu \mathrm{M}$ ) cells (Lin et al., 2003). Plumbagin induces apoptosis and cell cycle arrest in a smallcell lung cancer cells in vitro, inhibits tumor growth in vivo (Hsu et al., 2006) and has activity against promyelocytic leukemia cells in vivo (Xu \& Lu, 2009). It also significantly inhibits the growth of breast cancer cells and induces their apoptosis by inactivating NF$\kappa \mathrm{B}$ and $\mathrm{Bcl}-2$ without affecting normal breast epithelial cells (Ahmad et al., 2008). Moreover, this molecule exhibits cytotoxic activity (IC50 $14.6 \mu \mathrm{M}$ ) and inhibits microtubule polymerization in non-small-cell lung epithelial carcinoma cells in vitro (Acharya et al., 2008).

Psychotria ipecacuanha (Brot.) Stokes., Rubiaceae

Emetine works in synergy with doxorubicin, etoposide, oxaliplatin and docetaxel against three neuroendocrine tumor cell lines and it shows more cytotoxic activity than when emetine alone (Larsson et al., 2009). In addition, emetine induces apoptosis in some human tumor cell lines (Möller \& Wink, 2007). Emetine has been evaluated for the treatment of solid tumors, but no significant regression was observed in patients who were treated with this compound during a phase II clinical trial (Zhou et al., 2005; Siddiqui et al., 1973).

\section{Capsicum frutescens L., Solanaceae}

Capsaicin and other carotenoids isolated from the fruit of $C$. frutescens exhibit cancer chemopreventive activity in vitro and in vivo (Maoka et al., 2001). Capsaicin has cytotoxic effects and induces apoptosis in a melanoma cell line (Jun et al., 2007). It also induces cell cycle arrest (G0/G1) and apoptosis in a squamous cell carcinoma cell line of the esophagus (Wu et al., 2006) and inhibits cell proliferation and induces apoptosis in human glioblastoma (Gil \& Kang, 2008) and hepatocellular carcinoma cells (Jung et al., 2001). In addition, capsaicin inhibits the proliferation of pancreatic cancer cells and induces their apoptosis in vitro (IC50 $150 \mu \mathrm{M}$ ) and in vivo (Zhang et al., 2008). Moreover, capsaicin inhibits the growth of prostate tumor cells in vitro (IC50 $20 \mu \mathrm{M}$ ), suppresses their growth in vivo and induces their apoptosis in vivo and in vitro (Sánchez et al., 2006). Capsaicin also induces apoptosis of gastric cancer cells and normal cells, but the carcinogenic cells are more susceptible to the compound (Chow et al., 2007).

\section{Solanum americanum Mill., Solanaceae}

A 150-kDa glycoprotein isolated from the seeds of this plant exhibits cytotoxic activity and induces apoptosis in human colorectal carcinoma cells (Lee et al., 2004). S. americanum-derived polysaccharides have significant inhibitory activity against tumor growth in mice (Li et al., 2009; Li et al., 2007). In addition, the aqueous extract of this plant inhibits the growth of cervical carcinoma cells in mice by inducing cell cycle arrest (G0/G1) and apoptosis (Li et al., 2008). Solanine, an alkaloid, exhibits cytotoxic activity against human hepatocellular carcinoma cells (IC50 14.47 $\mu \mathrm{g} / \mathrm{mL}$ ) and induces their apoptosis (Ji et al., 2008). The ethanol extract of the ripe fruit inhibits cell growth and induces apoptosis of breast cancer cells (Son et al., 2003).

\section{Viola odorata L., Violaceae}

The acetone extract of $V$. odorata exhibits chemopreventive effects against DMBA-induced skin 
cancer in mice (Perwaiz \& Sultana, 1998). In addition, a macrocyclic peptide isolated from $V$. odorata, called cycloviolacin $\mathrm{O} 2$, exhibits in vitro cytotoxic activity against ten different cancer cell lines, including myeloma, leukemia, small-cell lung cancer, lymphoma and renal adenocarcinoma. It has an IC50 ranging between $0.1-0.3 \mu \mathrm{M}$ and gives better results than the anti-tumor drugs currently in clinical use (Lindholm et al., 2002).

\section{Conclusion}

Although there is generally a good in vitro and/ or in vivo activity of extracts, fractions or molecules isolated from brazilian medicinal plants popularly used for cancer, there is a need for further studies in order to assess the possibility of developing some by product.

We recommend that efforts are made to test hypotheses about effects observed (e.g, can compound A treat cancer? Did active compounds from B extract also show activity when isolated?). Thus, for plants that have only positive activity of extracts and/or fractions is necessary to elucidate the possible active compound(s) for further evaluation in vivo; and for plants with active molecules isolated with only in vitro and/or few in vivo studies are necessary a large number of pre-clinical studies to evaluate the efficacy and safety.

\section{Acknowledgements}

We thank CNPq and CAPES for its financial support to the authors.

\section{References}

Acevedo-Duncan M, Russell C, Patel S, Patel R 2004. Aloe-emodin modulates PKC isozymes, inhibits proliferation, and induces apoptosis in U-373MG glioma cells. Int Immunopharmacol 4: 1775-1784.

Acharya BR, Bhattacharyya B, Chakrabarti G 2008. The natural naphthoquinone plumbagin exhibits antiproliferative activity and disrupts the microtubule network through tubulin binding. Biochemistry-US 47: 7838-7845.

Agarwal C, Tyagi A, Kaur M, Agarwal R 2007. Silibinin inhibits constitutive activation of Stat3, and causes caspase activation and apoptotic death of human prostate carcinoma DU145 cells. Carcinogenesis 28: 1463-1470.

Ahmad A, Banerjee S, Wang Z, Kong D, Sarkar FH 2008. Plumbagin-induced apoptosis of human breast cancer cells is mediated by inactivation of NF-kB and Bcl-2. $J$ Cell Biochem 105: 1461-1471.

Ahmed-Belkacem A, Macalou S, Borrelli F, Capasso R, Fattorusso E, Taglialatela-Scafati O, Pietro AD 2007.
Nonprenylated rotenoids, a new class of potent breast cancer resistance protein inhibitors. J Med Chem 50: 1933-1938.

Akev N, Turkay G, Can A, Gurel A, Yildiz F, Yardibi H, Ekiz EE, Uzun H 2007. Tumour preventive effect of Aloe vera leaf pulp lectin (aloctin i) on Ehrlich ascites tumours in mice. Phytother Res 21: 1070-1075.

Alesiani D, Cicconi R, Mattei M, Montesano C, Bei R, Canini A 2008. Cell cycle arrest and differentiation induction by 5,7-dimethoxycoumarin in melanoma cell lines. Int $J$ Oncol 32: 425-434.

Ashidi JS, Houghton PJ, Hylands PJ, Efferth T 2010. Ethnobotanical survey and cytotoxicity testing of plants of South-western Nigeria used to treat cancer, with isolation of cytotoxic constituents from Cajanus cajan Millsp. Leaves. J Ethnopharmacol 128: 501512.

Bharali R, Azad MRH, Tabassum J 2003. Chemopreventive action of Boerhaavia diffusa on DMBA-induced skin carcinogenesis in mice. Indian $J$ Physiol Pharmacol 47: 459-464.

Bhatia N, Zhao J, Wolf DM, Agarwal R 1999. Inhibition of human carcinoma cell growth and DNA synthesisby silibinin, an active constituent of milk thistle: comparison with silymarin. Cancer Lett 147: 77-84.

Biswas SJ, Bhattacharjee N, Khuda-Bukhsh AR 2008. Efficacy of a plant extract (Chelidonium majus L.) in combating induced hepatocarcinogenesis in mice. Food Chem Toxicol 46: 1474-1487.

Breemen RBV, Pajkovic N 2008. Multitargeted therapy of cancer by lycopene. Cancer Lett 269: 339-351.

Calderón AI, Vázquez Y, Solís PN, Caballero-George C, Zacchino S, Gimenez A, Pinzón R, Cáceres A, Tamayo G, Correa M, Gupta MP 2006. Screening of latin american plants for cytotoxic activity. Pharm Biol 44: 130-140.

Chaturvedula VSP, Schilling JK, Malone S, Wisse JH, Werkhoven MCM, Kingston DG 2003. New cytotoxic triterpene acids from aboveground parts of Manihot esculenta from the Suriname rainforest. Planta Med 69: 271-274.

Chen S-H, Lin K-Y, Chang C-C, Fang C-L, Lin C-P 2007. Aloe-emodin-induced apoptosis in human gastric carcinoma cells. Food Chem Toxicol 45: 2296-2303.

Chen PN, Hsieh YS, Chiou HL, Chu SC 2005. Silibinin inhibits cell invasion through inactivation of both PI3K-Akt and MAPK signaling pathways. Chem-Biol Interact 156: 141-150.

Choi BT, Cheong JH, Choi YH 2003a. $\beta$-Lapachone-induced apoptosis is associated with activation of caspase-3 and inactivation of NF-jB in human colon câncer HCT-116 cells. Anti-Cancer Drugs 14: 845-850.

Choi YH, Kang HS, Yoo MA 2003b. Suppression of human prostate cancer cell growth by $\beta$-lapachone via downregulation of $\mathrm{pRB}$ phosphorylation and induction of 
Cdk inhibitor p21. J Biochem Mol Biol 36: 223-229.

Chow J, Norng M, Zhang J, Chai J 2007. TRPV6 mediates capsaicin-induced apoptosis in gastric cancer cellsMechanisms behind a possible new "hot" cancer treatment. Biochim Biophys Acta 1773: 565-576.

Cordero CP, Gómez-González S, León-Acosta CJ, MorantesMedina SJ, Aristizabal FA 2004. Cytotoxic activity of five compounds isolated from Colombian plants. Fitoterapia 75: 225-227.

Costa PM, Ferreira PMP, Bolzani VS, Furlan M, Santos VAFFM, Corsino J, Moraes MO, Costa-Lotufo LV, Montenegro RC, Pessoa C 2008. Antiproliferative activity of pristimerin isolated from Maytenus ilicifolia (Celastraceae) in human HL-60 cells. Toxicol in Vitro 22: 854-863.

Costa-Lotufo LV, Cunha GMA, Farias PAM, Viana GSB, Cunha KMA, Pessoa C, Moraes MO, Silveira ER, Gramosa NV, Rao VSN 2002. The cytotoxic and embryotoxic effects of kaurenoic acid, a diterpene isolated from Copaifera langsdorffii oleo-resin. Toxicon 40: 1231-1234.

Davis-Searles PR, Nakanishi Y, Kim NC, Graf TN, Oberlies NH, Wani MC, Wall ME, Agarwal R, Kroll DJ 2005. Milk thistle and prostate cancer: differential effects of pure flavonolignans from silybum marianum on antiproliferative end points in human prostate carcinoma cells. Cancer Res 65: 4448-4457.

Deep G, Agarwal R 2007. Chemopreventive efficacy of silymarin in skin and prostate cancer. Integr Cancer Ther 6: 130-145.

Efferth T, Olbrich A, Sauerbrey A, Ross DD, Gebhart E, Neugebauer M 2002. Activity of ascaridol from the anthelmintic herb Chenopodium anthelminticum L. against sensitive and multidrug-resistant tumor cells. Anticancer Res 22: 4221-4224.

Endringer DC, Pezzuto JM, Braga FC 2009. NF-Kb inhibitory activity of cyclitols isolated from Hancornia speciosa. Phytomedicine 16: 1064-1069.

Furukawa F, Nishikawa A, Chihara T, Shimpo K, Beppu H, Kuzuya H, Lee I-S, Hirose M 2002. Chemopreventive effects of Aloe arborescens on N-nitrosobis(2oxopropyl)amine-induced pancreatic carcinogenesis in hamsters. Cancer Lett 178: 117-122.

Gálvez M, Martín-Cordero C, López-Lázaro M, Cortés F, Ayuso MJ 2003. Cytotoxic effect of Plantago spp. on cancer cell lines. J Ethnopharmacol 88: 125-130.

Gansauge F, Ramadani M, Pressmar J, Gansauge S, Muehling B, Stecker K, Cammerer G, Leder G, Beger HG 2002. NSC-631570 (Ukrain) in the palliative treatment of pancreatic câncer Results of a phase II Trial. Langenbecks Arch Surg 386: 570-574.

Gansauge F, Ramadani M, Gansauge S 2001. Cytotoxic effects of the alkaloid chelidonine from Chelidonium majus on pancreatic cancer cells. an old and highly potent anticancer drug. Gastroenterology 120: A617A618.
Gil Y-G, Kang M-K 2008. Capsaicin induces apoptosis and terminal differentiation in human glioma A172 cells. Life Sci 82: 997-1003.

Gomes NM, Rezende CM, Fontes SP, Hovell AMC, Landgraf RG, Matheus ME, Pinto AC, Fernandes PD 2008. Antineoplasic activity of Copaifera multijuga oil and fractions against ascitic and solid Ehrlich tumor. $J$ Ethnopharmacol 119: 179-184.

Gupta D, Podar K, Tai Y-T, Lin B, Hideshima T, Akiyama M, LeBlanc R, Catley L, Mitsiades N, Mitsiades C, Chauhan D, Munshi NC, Anderson KC 2002. $\beta$-lapachone, a novel plant product, overcomes drug resistance in human multiple myeloma cells. Exp Hematol 30: 711-720.

Habermehl D, Kammerer B, Handrick R, Eldh T, Gruber C, Cordes N, Daniel PT, Plasswilm L, Bamberg M, Belka C, Jendrossek V 2006. Proapoptotic activity of Ukrain is based on Chelidonium majus L. alkaloids and mediated via a mitochondrial death pathway. BMC Cancer 6: 14.

Hoh CSL, Boocock DJ, Marczylo TH, Brown VA, Cai H, Steward WP, Berry DP, Gescher AJ 2007. Quantitation of silibinin, a putative cancer chemopreventive agent derived from milk thistle (Silybum marianum), in human plasma by high-performance liquid chromatography and identification of possible metabolites. J Agric Food Chem 55: 2532-2535.

Hsu Y-L, Cho C-Y, Kuo P-L, Huang Y-T, Lin C-C 2006. Plumbagin (5-Hydroxy-2-methyl-1,4naphthoquinone) induces apoptosis and cell cycle arrest in A549 cells through p53 accumulation via c-Jun NH2-terminal kinase-mediated phosphorylation at serine 15 in vitro and in vivo. J Pharmacol Exp Ther 318: 484-494.

Idibie CA, Davids H, Iyuke SE 2007. Cytotoxicity of purified cassava linamarin to a selected cancer cell lines. Bioprocess Biosyst Eng. 30: 261-269.

Itharat A, Houghton PJ, Eno-Amooquaye E, Burke PJ, Sampson JH, Raman A 2004. In vitro cytotoxic activity of Thai medicinal plantsused traditionally to treat câncer. J Ethnopharmacol 90: 33-38.

Ji YB, Gao SY, Ji CF, Zou X 2008. Induction of apoptosis in HepG2 cells by solanine and Bcl-2 protein. $J$ Ethnopharmacol 115: 194-202.

Jiménez-Medina E, Garcia-Lora A, Paco L, Algarra I, Collado A, Garrido F 2006. A new extract of the plant calendula officinalis produces a dual in vitro effect: cytotoxic anti-tumor activity and lymphocyte activation. $B M C$ Cancer 6: 119.

Jin GZ, Quan HJ, Koyanagi J, Takeuchi K, Miura Y, Komada F, Saito S 2005. 4'-O-Alkyaloenin derivatives and their sulfates directed toward overcoming multidrug resistance in tumor cells. Cancer Lett 218: 15-20.

Jun HS, Park T, Lee CK, Kang MK, Park MS, Kang H1, Surh Y-J, Kim OH 2007. Capsaicin induced apoptosis of 
B16-F10 melanoma cells through down-regulation of Bcl-2. Food Chem Toxicol 45: 708-715.

Jung M-Y, Kang H-J, Moon A 2001. Capsaicin-induced apoptosis in SK-Hep-1 hepatocarcinoma cells involves Bcl-2 downregulation and caspase-3 activation. Cancer Lett 165: 139-145.

Kemény-Beke A, Aradi J, Damjanovich J, Beck Z, Facskó A, Berta A, Bodnár A 2006. Apoptotic response of uveal melanoma cells upon treatment with chelidonine, sanguinarine and chelerythrine. Cancer Lett 237: $67-$ 75.

Kim S, Choi JH, Lim HI, Lee SK, Kim WW, Kim JS, Kim J-H, Choe J-H, Yang J-H, Nam SJ, Lee JE 2009. Silibinin prevents TPA-induced MMP-9 expression and VEGF secretion by inactivation of the Raf/MEK/ ERK pathway in MCF-7 human breast cancer cells. Phytomedicine 16: 573-580.

Kim SO, Kwon JI, Jeong YK, Kim GY, Kim ND, Choi YH 2007. Induction of Egr-1 is associated with antimetastatic and anti-invasive ability of beta-lapachone in human hepatocarcinoma cells. Biosci Biotechnol Biochem 71: 2169-2176.

Lanvers-Kaminsky C, Nolting DM, Koster J, Schroder A, Sandkotter J, Boos J 2006. In vitro toxicity of Ukrain against human Ewing tumor cell lines. Anti-Cancer Drugs 17: 1025-1030.

Larsson DE, Hassan S, Larsson R, Oberg K, Granberg D 2009. Combination analyses of anti-cancer drugs on human neuroendocrine tumor cell lines. Cancer Chemother Pharmacol 65: 5-12.

Lee JI, Choi DY, Chun HS, Seo HG, Woo HJ, Choi BT, Choi YH 2006. $\beta$-lapachone induces growth inhibition and apoptosis in bladder cancer cells by modulation of bcl-2 family and activation of caspases. Exp Oncol 28: 30-35.

Lee JH, Cheong JH, Park YM, Choi YH 2005. Downregulation of cyclooxygenase-2 and telomerase activity by $\beta$-lapachone in human prostate carcinoma cells. Pharmacol Res 51: 553-560.

Lee S-J, Oh P-S, Ko J-H, Lim K, Lim K-T 2004. A 150$\mathrm{kDa}$ glycoprotein isolated from Solanum nigrum L. has cytotoxic and apoptotic effects by inhibiting the effects of protein kinase $\mathrm{C}$ alpha, nuclear factor-kappa $\mathrm{B}$ and inducible nitric oxide in HCT-116 cells. Cancer Chemother Pharmacol 54: 562-572.

Leyon PV, Lini CC, Kuttan G 2005. Inhibitory effect of Boerhaavia diffusa on experimental metastasis by B16F10 melanoma in C57BL/6 mice. Life Sci 76: 1339-1349.

Li J, Li Q-W, Gao D-W, Han Z-S, Lu W-Z 2009. Antitumor and immunomodulating effects of polysaccharides isolated from Solanum nigrum Linne. Phytotherapy Research 23: 1524-1530.

Li J, Li Q, Feng T, Li.K 2008. Aqueous extract of Solanum nigrum inhibit growth of cervical carcinoma (U14) via modulating immune response of tumor bearing mice and inducing apoptosis of tumor cells. Fitoterapia 79: 548-556.

Li J, Li Q, Feng T, Zhang T, Li K, Zhao R, Han Z, Gao D 2007. Antitumor activity of crude polysaccharides isolated from Solanum nigrum Linne on U14 Cervical Carcinoma Bearing Mice. Phytotherapy Res 21: 832840.

Lim H, Kim MK, Lim Y, Cho YH, Lee CH 2006. Inhibition of cell-cycle progression in HeLa cells by HY52, a novel cyclin-dependent kinase inhibitor isolated from Bauhinia forficata. Cancer Lett 233: 89-97.

Lima SEM, Veiga Junior VF, Christo HB, Pinto AC, Fernandes PD 2003. In vivo and in vitro studies on the anticancer activity of Copaifera multijuga Hayne and its fractions. Phytotherapy Res 17: 1048-1053.

Lin JG, Chen GW, Li TM, Chouh ST, Tan TW, Chung JG 2006. Aloe-emodin induces apoptosis in T24 human bladder cancer cells through the p53 dependent apoptotic pathway. J Urol 175: 343-347.

Lin LC, Yang LL, Chou CJ 2003. Cytotoxic naphthoquinones and plumbagic acid glucosides from Plumbago zeylanica. Phytochemistry 62: 619-622.

Lindholm P, Goransson U, Johansson S, Claeson P, Gullbo J, Larsson R, Bohlin L, Backlund A 2002. Cyclotides: A novel type of cytotoxic agents. Mol Cancer Ther 1: 365-369.

Lissoni P, Rovelli F, Brivio F, Zago R, Colciago M, Messina G, Mora A, Porro G 2009. A randomized study of chemotherapy Versus biochemotherapy with chemotherapy plus Aloe arborescens in patients with metastatic cancer. In vivo 23: 171-176.

Manu KA, Kuttan G 2009. Anti-metastatic potential of Punarnavine, na alkaloid from Boerhaavia diffusa Linn. Immunobiology 214: 245-255.

Maoka T, Mochida K, Kozuka M, Ito Y, Fujiwara Y, Hashimoto K, Enjo F, Ogata M, Nobukuni Y, Tokuda H, Nishino H. 2001. Cancer chemopreventive activity of carotenoids in the fruits of red paprika Capsicum annuum L. Cancer Lett 172: 103-109.

Melo JG, Martins JDGR, Amorim ELC, Albuquerque UP 2007. Qualidade de produtos a base de plantas medicinais comercializados no Brasil: castanha-daíndia (Aesculus hippocastanum L.), capim-limão (Cymbopogon citratus (DC.) Stapf) e centela (Centella asiatica (L.) Urban). Acta Bot Bras 2: 27-36.

Melo JG, Santos AG, Amorim ELC, Nascimento SC, Albuquerque UP 2011. Medicinal plants used as antitumor agents in Brazil: an ethnobotanical approach. Evid-Based Compl Alt 2011: 1-14.

Mesquita ML, Paula JE, Pessoac C, Moraes MO, Costa-Lotufo LV, Grougnet R, Michel S, Tillequin F, Espindola LS 2009. Cytotoxic activity of Brazilian Cerrado plants used in traditional medicine against cancer cell lines. J Ethnopharmacol 123: 439-445. 
Miyoshi N, Uchida K, Osawa T, Nakamura Y 2006. Selective cytotoxicity of benzyl isothiocyanate in the proliferating fibroblastoid cells. Int $J$ Cancer 120: 484-492.

Möller M, Wink M 2007. Characteristics of apoptosis induction by the alkaloid emetine in human tumour cell lines. Planta Med 73: 1389-1396.

Monthé CG, Souza IA, Calazans GMT 2008. Antitumor activity of cashew gum from Anacardium occidentale L. Agro Food Ind Hi tec 19: 50-52.

Moretão MP, Zampronio AR, Gorin PAJ, Iacomini M, Oliveira MBM 2004. Induction of secretory and tumoricidal activities in peritoneal macrophages activated by an acidic heteropolysaccharide (ARAGAL) from the gum of Anadenanthera colubrina (Angico branco). Immunol Lett 93: 189-197.

Mothana RA, Lindequist U, Gruenert R, Bednarski PJ 2009. Studies of the in vitro anticancer, antimicrobial and antioxidant potentials of selected Yemeni medicinal plants from the island Soqotra. BMC Complem Altern M 9: 7.

Nakamura Y, Yoshimoto M, Murata Y, Shimoishi Y, Asai Y, Park EY, Sato K, Nakamura Y 2007. Papaya seed represents a rich source of biologically active isothiocyanate. J Agric Food Chem 55: 4407-4413.

Nascimento FRF, Cruz GVB, Pereira PVS, Maciel MCG, Silva LA, Azevedo APS, Barroqueiro ESB, Guerra RNM 2006. Ascitic and solid Ehrlich tumor inhibition by Chenopodium ambrosioides L. treatment. Life Sci 78 : 2650-2653.

Nawrot R, Wolun-Cholewa M, Gozdzicka-Józefiak A 2008. Nucleases isolated from Chelidonium majus L. milky SAP can induce apoptosis in human cervical carcinoma HeLa cells but not in Chinese Hamster Ovary CHO cells. Folia Histochem Cyto 46: 79-83.

Nguyen AT, Malonne H, Duez P, Vanhaelen-Fastre R, Vanhaelen M, Fontaine J 2004. Cytotoxic constituents from Plumbago zeylanica. Fitoterapia 75: 500-504.

Ohsaki A, Imai Y, Naruse M, Ayabe S, Komiyama K, Takashima J 2004. Four new triterpenoids from Maytenus ilicifolia. J Nat Prod 67: 469-471.

Oliveira FC, Albuquerque UP, Fonseca-Kruel VS, Hanazaki N 2009. Avanços nas pesquisas etnobotânicas no Brasil. Acta Bot Bras 23: 590-605.

Ozaslan M, Karagöz ID, Kalender ME, Kilic IH, Sari I, Karagöz A 2007. In vivo antitumoral effect of Plantago major L. extract on balb/C mouse with Ehrlich ascites tumor. $\mathrm{Am} J$ Chinese Med 35: 841-851.

Paramashivappa R, Kumar PP, Vithayathil PJ, Rao AS 2001. Novel method for isolation of major phenolic constituents from cashew (Anacardium occidentale L.) nut shell liquid. J Agric Food Chem 49: 25482551.

Park HJ, Ahn K-J, Ahn S-D, Choi E, Lee SW, Williams B, Kim EJ, Griffin R, Bey EA, Bornmann WG, Gao J, Park
HJ, Boothman DA, Song CW 2006. Susceptibility of cancer cells to lapachone is enhanced by ionizing radiation. Int J Radiation Oncology Biol Phys 61: 212-219.

Pecere T, Gazzola MV, Mucignat C, Parolin C, Vecchia FD, Cavaggioni A, Basso Giuseppe, Diaspro A, Salvato B, Carli M, Palú G 2000. Aloe-emodin is a new type of anticancer agent with selective activity against neuroectodermal tumors. Cancer Res 60: 2800-2804.

Perwaiz S, Sultana S 1998. Antitumorigenic effect of crude extract of Viola odorata on DMBA- induced two stage skin carcinogenesis in the Swiss albino mice. Asia Pac J Pharmacol 13: 43-50.

Rajendran NN, Deepa N 2007. Anti-tumor activity of acanthospermum hispidum DC on dalton ascites lymphoma in mice. Nat Prod Sci 13: 234-240.

Ramasamy K, Agarwal R 2008. Multitargeted therapy of cancer by silymarin. Cancer Lett 269: 352-362.

Rea AI, Schmidt JM, Setzer WN, Sibanda S, Taylor C, Gwebu ET 2003. Cytotoxic activity of Ozoroa insignis from Zimbabwe. Fitoterapia 74: 732-735.

Rennó MN, Barbosa GM, Zancan P, Veiga VF, Alviano CS, Sola-Penna M, Menezes FS, Holandino C 2008. Crude ethanol extract from babassu (Orbignya speciosa): cytotoxicity on tumoral and non-tumoral cell lines. An Acad Bras Cienc 80: 467-476.

Roman GP, Neagu E, Moroeanu V, Radu GL 2008. Concentration of Symphytum officinale extracts with cytostatic activity by tangential flow ultrafiltration. Roumanian Biotechnological Letters 13: 4008-4013.

Sánchez AM, Sánchez MG, Malagarie-Cazenave S, Olea N, Díaz-Laviada I 2006. Induction of apoptosis in prostate tumor PC-3 cells and inhibition of xenograft prostate tumor growth by the vanilloid capsaicin. Apoptosis 11: 89-99.

Scambia G, Vincenzo R, Ranelletti FO, Panici PB, Ferrandina G, D’Agostino G, Fattorossi A, Bombardelli E, Mancuso S 1996. Antiproliferative effect of silybin on gynaecological malignancies: synergism with cisplatin and doxorubicin. Eur J Cancer 32: 877-882.

Shirota O, Moritak H, Akjxa O, Itokawa H 1994. Cytotoxic aromatic triterpenes from Maytenus ilicifolia and Maytenus chuchuhuasca. J Nat Prod 57: 1675-1681.

Siddiqui S, Firat D, Olshin S 1973. Phase II study of emetine (NSC-33669) in the treatment of solid tumors. Cancer Chemother Rep 57: 423-428.

Singh RP, Agarwal R 2005. Mechanisms and preclinical efficacy of silibinin in preventing skin câncer. Eur $J$ Cancer 41: 1969-1979.

Smith JA, Poteet-Smith CE, Xu Y, Errington TM, Hecht SM, Lannigan DA 2005. Identification of the first specific inhibitor of p90 ribosomal S6 Kinase (RSK) reveals an unexpected role for RSK in câncer cell proliferation. Cancer Res 65: 1027-1034.

Son Y.-O, K im J, Lim J.-C, Chung Y, Chung G.-H, Lee J.-C 
2003. Ripe fruits of Solanum nigrum L. inhibits cell growth and induces apoptosis in MCF-7 cells. Food Chem Toxicol 41: 1421-1428.

Sun Y, Jiang X, Chen S, Price BD 2006. Inhibition of histone acetyltransferase activity by anacardic acid sensitizes tumor cells to ionizing radiation. FEBS Lett 580: 4353-4356.

Sung B, Pandey MK, Ahn KS, Yi T, Chaturvedi MM, Liu M, Aggarwal BB 2008. Anacardic acid (6-nonadecyl salicylic acid), an inhibitor of histone acetyltransferase, suppresses expression of nuclear factor- $\mathrm{kB}$-regulated gene products involved in cell survival, proliferation, invasion, and inflammation through inhibition of the inhibitory subunit of nuclear factor- $\mathrm{kB} \alpha$ kinase, leading to potentiation of apoptosis. Blood 111: 4880-4891.

Tyagi A, Bhatia N, Condon MS, Bosland MC, Agarwal C, Agarwal R 2002. Antiproliferative and apoptotic effects of silibinin in rat prostate cancer cells. The Prostate 53: 211-217.

Ukiya M, Akihisa T, Yasukawa K, Tokuda H, Suzuki T, Kimura Y 2006. Anti-inflammatory, anti-tumorpromoting, and cytotoxic activities of constituents of marigold (Calendula officinalis) Flowers. J Nat Prod 69: 1692-1696.

Velasco-Lezama R, Tapia-Aguilar R, Román-Ramos R, VegaAvila E, Pérez-Gutiérrez MS 2006. Effect of Plantago major on cell proliferation in vitro. J Ethnopharmacol 103: 36-42.

Vicente G 2009. Nonsurgical treatment of basal cell carcinoma using cashew extract. Otolaryng Head Neck 141: 44.

Wasserman L, Avigad S, Beery E, Nordenberg J, Fenig E 2002. The effect of aloe emodin on the proliferation of a new merkel carcinoma cell line. Am J Dermatopath 24: 17-22.

Woo HJ, Park K-Y, Rhu C-H, Lee WH, Choi BT, Kim GY, Park Y-M, Choi YH 2006. $\beta$-lapachone, a quinone isolated from Tabebuia avellanedae, induces apoptosis in HepG2 hepatoma cell line through induction of bax and activation of caspase. J Med Food 9: 161-168.

Wu C-C, Lin J-P, Yang J-S, Chou S-T, Chen S-C, Lin Y-T, Lin H-L, Chung J-G 2006. Capsaicin induced cell cycle arrest and apoptosis in human esophagus epidermoid carcinoma CE $81 \mathrm{~T} / \mathrm{VGH}$ cells through the elevation of intracellular reactive oxygen species and $\mathrm{Ca} 2+$ productions and caspase-3 activation. Mutation

\section{Research 601: 71-82.}

Xu K-H, Lu D-P 2009. Plumbagin induces ROS-mediated apoptosis in human promyelocytic leukemia cells in vivo. Leukemia Res 34: 658-665.

Xu Y, Smith JA, Lannigan DA, Hecht SM 2006. Three acetylated flavonol glycosides from Forsteronia refracta that specifically inhibit p90 RSK. Bioorgan Med Chem 14: 3974-3977.

Yang H, Landis-Piwowar KR, Lu D, Yuan P, Li L, Reddy GPV, Yuan X, Dou QP 2008. Pristimerin induces apoptosis by targeting the proteasome in prostate cancer cells. $J$ Cell Biochem 103: 234-244.

Yang SF, Chu SC, Liu SJ, Chen YC, Chang YZ, Hsieh YS 2007. Antimetastatic activities of Selaginella tamariscina (Beauv.) on lung cancer cells in vitro and in vivo. J Ethnopharmacol 110: 483-489.

Yusuf UF, Ahmadun FR, Rosli R, Iyuke SE, Billa N, Abdullah $\mathrm{N}$, Umar-Tsafe $\mathrm{N}$ 2006. An in vitro inhibition of human malignant cell growth of crude water extract of cassava (Manihot esculenta Crantz) and commercial linamarin. Nutraceutical and Functional Food 28: 145-155.

Zhang R, Humphreys I, Sahu RP, Shi Y, Srivastava SK 2008. In vitro and in vivo induction of apoptosis by capsaicin in pancreatic cancer cells is mediated through ROS generation and mitochondrial death pathway. Apoptosis 13: 1465-1478.

Zhong X, Zhu Y, Lu Q, Zhang J, Ge Z, Zheng S 2006. Silymarin causes caspases activation and apoptosis in K562 leukemia cells through inactivation of Akt pathway. Toxicology 227: 211-216.

Zhou Y-D, Kim Y-P, Mohammed KA, Jones DK, Muhammad I, Dunbar DC, Nagle DG 2005. Terpenoid tetrahydroisoquinoline alkaloids emetine, klugine, and isocephaeline inhibit the activation of hypoxiainducible factor-1 in breast tumor cells. J Nat Prod 68: 947-950.

\section{*Correspondence}

Ulysses Paulino de Albuquerque

Departamento de Biologia, Universidade Federal Rural de Pernambuco

Rua Dom Manoel de Medeiros s/n, Recife-PE, Brazil

upa@db.ufrpe.br

Tel.: +558133206350 